DOI 10.37882/2500-3682.2021.04.02

\title{
ОТ СОГЛАСИЯ К ЕДИНСТВУ И КОНСОЛИДАЦИИ РОССИЙСКОГО ОБЩЕСТВА
}

\section{FROM CONSENT TO UNITY AND CONSOLIDATION OF RUSSIAN SOCIETY}

I. Bokachev I. Neznamova

Summary: The article presents the author's points of view on the concept of «consent», which is very actively used in the domestic social and political areas, in the discussions of experts, and in daily rhetoric of political and public figures. The arguments "for» and «against» this phenomenon are expressed, and its bifurcation nature is determined. Multicultural unity and consolidation of Russian society are proposed as the most important requirements of our time as well as the main conditions for further development of the country.

Keywords: consent, consolidation and unity of society, patriotism, conformism, multicultural relations, Russian language and culture, political alienation.

\author{
Бокачев Иван Афанасьевич \\ Д.ф.н., профессор, Северо-Кавказский федеральный \\ университет, Ставрополь. \\ Незнамова Ирина Ивановна \\ К.ф.н., Ставропольский филиал Московского \\ гуманитарно-экономического университета, \\ Ставрополь. \\ irinanez@yandex.ru
}

Аннотация: В статье представлен авторский взгляд на концепт «согласие», который весьма активно используется в отечественном общественно-политическом аспекте, в дискуссиях экспертных сообществ, практически в ежедневной риторике политических и общественных деятелей. Высказываются аргументы «за» и «против» данного феномена, определяется его бифуркационная природа. В качестве важнейших требований времени, главных условий дальнейшего развития страны предлагаются межнациональное единство и консолидация российского общества.

Ключевые слова: согласие, консолидация и единство общества, патриотизм, конформизм, межэтнические отношения, русский язык и культура, политическая алиенация.

ное общество характеризуется конфликтностью, внутренней неустойчивостью и непредсказуемостью, все более быстрым темпом изменений во всех его сферах. В таких условиях становятся весьма востребованными согласованные действия как между государством и обществом, так и внутри обозначенных феноменов, между политическими и общественными организациями, представителями различных партий, конфессий и этнических образований.

Очевидно и другое. Согласие не тот концепт, с помощью которого можно решать назревшие проблемы. Ретроспективный взгляд в историю показывает, что согласие всегда имело не только позитивный, но и негативный аспект. С молчаливого согласия людей власть имущие утверждались в своей непогрешимости, их мнение, как правило, становилось мнением в последней инстанции. Мнение же основной массы населения если и учитывалось, то только в декларативном плане, создавалась иллюзия коммуникативного диалога с людьми. Речь идет о так называемой политической алиенации, об отчуждении власти от общества и от своих граждан. Именно политическое отчуждение и характеризовало отечественный социум практически на всех этапах его истории. В результате в обществе имело место быть взаимное недоверие и как следствие того - отсутствие подлинного, а не мнимого согласия. На этом фоне зарождались и утверждались культ личности, тоталитаризм, система централизованного бюрократизма, волюнтаризм, тоталитарная элита и 
партократия, которая практически оформилась в класс и отгородилась теперь уже разрушенной «Берлинской стеной» не только от своих членов, но и от всего народа.

B XX веке мы пережили «перестройку», которая опиралась не на волю и желание народа, а на обыденный уровень сознания ограниченного круга политиков и политиканов, а так же «...самую большую трагедию» (В.В. Путин) - развал Советского Союза, так называемые «реформы» младодемократов, которые завели государство в тупик из которого придётся выбираться возможно ещё не одно десятилетие. Казалось бы, на фоне подобных потрясений просто не подобает говорить о таких «мелочах» как уничтожение в свое время виноградников, затопление космической станции «Мир», закрытие станции слежения на Кубе, оставленные базы в Камрани (Вьетнам) и многие другие явления нашей действительности. Всё это результат «согласия», которого у народа никто не спрашивал и последствия которого приходится устранять нынешнему руководству страны, прилагая титанические усилия и расходуя огромные материальные и финансовые средства.

Данные обстоятельства подтверждают как очевидное: согласие имеет бифуркационную природу. С одной стороны оно возможно и необходимо, особенно на уровне межгосударственных отношений, при решении сложных, противоречивых и неотложных проблем современности, а также в политическом пространстве своей страны. Без политического согласия сегодня не смогли бы работать ни исполнительная, ни законодательная власти. Согласие и взаимопонимание здесь предстают в качестве доминанты успешной деятельности всех уровней государственного организма. То же следует сказать о согласии и в межэтнических, межнациональных отношениях. В данном случае согласие нередко рассматривается в качестве главного условия современного развития России $[3, c .175]$. Трудно возразить против подобного рода точек зрения. Действительно межнациональное согласие в определённых условиях способствует предотвращению насильственных конфликтов, легитимации в массовом сознании таких отношений между различными этносами, которые направлены не на их разрушение, а на созидание.

С другой стороны согласие не имеет и не может иметь, скажем так, стратегических, далеко идущих целей. Оно призвано решать назревшие, не терпящие отлагательства проблемы. Если же эти проблемы «консервируются» на протяжении длительного времени, не принимаются меры по их устранению, то с течением времени согласие ведёт к обострению существующих противоречий, перерастает в конфликт. Согласие - это некий штамм, понятие с вялой психосемантикой. Его можно поставить в один категориальный ряд с такими понятиями как толерантность, индифирентность, аморфность, аномия и другие.
В конечном итоге согласие - это результат безмолвной покорности. В обстановке постоянного согласия и безответственности за принимаемые решения индивид постепенно превращается в Homo gelius- желеобразного человека, сознанием и поведением которого можно легко управлять и манипулировать. Для него характерно отсутствие собственной позиции, некритическое, а порой и беспринципное следование любому шаблону или образцу, который имеет в данной ситуации наибольшую силу давления. С течением времени согласие вырабатывает у человека приспособленчество, способствует пассивному принятию существующего порядка вещей, господствующего мнения и т.п., что ведет к конформизму.

Конформное поведение можно встретить там, где в случаях расхождения во мнении между группой и индивидом, последний уступает, поддается групповому давлению. Однако до бесконечности человек уступать не может. Он, как своего рода пружина, может сжиматься до какого-то предела, а как только давление ослабевает или вовсе прекращается индивид выходит из-под контроля и снова начинает действовать в соответствии со своими личностными установками. И на это есть основания. Известно, что каждая личность имеет, во всяком случае, должна иметь, свой уровень самостоятельности, независимости и нравственности, опуститься ниже которого она не сможет ни при каких обстоятельствах и на базе которых она вырабатывает своё мнение о том или ином явлении и отстаивает его перед оппонентами. В противном случае человек рискует потерять своё достоинство и компетентность, уверенность в себе не только на данном участке работы, но и в жизни в целом.

Это еще раз подтверждает мысль о том, что согласие не имеет прочной ни духовно-нравственной, ни гносеологической основы. Оно в значительной мере отражает явление, а не сущность, что позволяет нам еще больше утвердиться во мнении, что мы живем во времена восстания явлений против сущности. По-видимому, можно даже сказать, что в этом понятии порой содержится доведенная до абсурда политика политкорректности и мультикультурализма. Это же в полной мере относится и к межнациональным отношениям. Здесь согласие может стать доминирующим только в случае массового клонирования человека или пересадки голов ( о чем не в столь отдаленные времена шел разговор даже на уровне научного сообщества) и превращение общества таким образом в безликую массу людей, для которых выражение: «Делай, что говорят и ни о чем больше не думай!», станет непреложным законом их жизни. Говоря словами французского философа, теолога Б. Паскаля, человек в таком случае лишается своей сущности, теряет свое величие способность мыслить.

Все это дает основание полагать, что сегодня важно вести речь не столько о согласии, сколько о консоли- 
дации общества, о его единстве и целостности. Консолидация предполагает упрочение сплоченности, как отдельных граждан, так и общественных организаций и конфессиональных объединений для усиления борьбы за общие цели, ценности (в первую очередь духовнонравственные) и решение стоящих перед обществом созидательных задач. Консолидация является непреложной предтечей единства и целостности. Именно в единстве наша сила (В.В. Путин). Причем проблема единства не является неким директивным понятием, или чьим-то вымыслом. Единство российской общности обусловлено исторической судьбой наших народов, той средой, в которой на протяжении многих десятков веков складывались и утверждались межэтнические отношения. Единство наших народов являет собой тот главный стержень прогресса вокруг которого консолидируются не только отдельные граждане, но и самые разные политические и общественные структуры, включая конфессиональные объединения.

Единство в современной литературе предстает как понятие, «...характеризующее значительный объем и высокий уровень взаимосогласованных позиций, связей между субъектами общественных отношений на базе решения ими конкретных проблем и взаимодействия» [4,с.105-106].Оно является той фундаментальной духовно-нравственной ценностью на базе которой происходит осознание нами исторической ответственности перед настоящим и будущими поколениями, перед своим народом, перед обществом и страной в целом.

Составной частью единства является национальное единство, которое может и должно выступать в качестве одного из необходимых условий, своего рода гарантии сохранения национальной безопасности России как суверенного государства. «...Национальное единство страны - это, прежде всего, единство представлений ее народа о наиболее значимых духовных ценностях» [5,c.3]. Ядро национального единства составляют ценностно-смысловые основания национально-культурной идентичности, которую разделяют все жители нашей страны. Именно они, а не принадлежность людей к тому или иному этносу, конфессии обеспечивают в большей мере сплочение народа, делают его единой нацией и создают специфические особенности психического склада людей, менталитета. На базе ценностно-смысловых оснований и формируется то стратегически важное качество народа, которое и призвано стать основой национального единства.

Национальное единство в большей мере проявляет себя в условиях, когда этнос в массе своей - одинаково реагирует как на внутренние проблемы, так и на проявления угрозы из вне. Другими словами, если среди различных общественных (социальных), этнических и религиозных групп и объединений не наблюдается кар- динальных расхождений в реакции на существующие угрозы, то с определенной долей уверенности можно утверждать - в данной стране имеет место национальное единство.

Ярким подтверждением тому могут служить проявления единства в оценке событий в связи с возвращением Крыма в родную гавань, на Востоке Украины. Единство и общность, рост национального самосознания, гордость за свою страну вызвали торжества по случаю крещения Руси князем Владимиром, празднование 75-летия Победы в Великой Отечественной войне и другие. У нас в стране одна нация, один российский народ, объединяющий огромное количество этносов, представителей многочисленных конфессий, трех мировых религий. Именно об этом говорится в документах, представленных различными политическими партиями на уровне Государственной Думы РФ. Особого внимания, в данном контексте, заслуживают проекты: «Декларация национального единства и гражданской солидарности», «Декларация национального единства народа России». Оба проекта вполне можно было бы представить на Всероссийский референдум в качестве своего рода общественного договора, который открывал бы путь для ведения конструктивного межэтнического диалога.

В связи с этим уже сегодня важным представляется формирование у наших этносов культуры межнационального общения, патриотизма, коллективизма, дружбы, межнационального и межконфессионального взаимопонимания. Время настоятельно требует: избавляться от этнической кичливости и заносчивости, утверждать общечеловеческие ценности, гуманизм, уважение к национальной специфике, к положительным обычаям и традициям других этносов, к их культуре и языку. Сегодня уже недостаточно ограничиваться таким понятием как "толерантность», которое вошло в обязательный идеологический ассортимент. Именно в толерантности часто усматривается ключ к разрешению конфликта культур и идентичностей, некоторые государственные и общественные деятели видят в ней панацею от всех бед и проблем. Принято считать, что стоит только усвоить всем нам данную установку и в обществе воцарится гармония и порядок. Вне всякого сомнения - это благие намерения, но они, как нам представляется, таят в себе некоторую упрощенность и даже наивность. Толерантность, как и согласие, о чем было сказано выше, «...это концепт с «вялой» психосоматикой, реально очень часто означающий лишь безразличие или даже снисхождение к иному. Поэтому сама по себе толерантность исключает взаимодействие культур, без чего между ними невозможно установить отношения диалога» $[6$, с.78]. Даже РПЦ отказалась от употребления этого понятия в своем обиходе.

Сегодня нужны другие подходы. Межэтнические от- 
ношения должны строиться на исконно российских ценностях, важнейшими из которых во все времена были любовь и уважение. В связи с этим главная задача всех государственных и общественных структур - помочь людям обрести уважение к любому народу, населяющему нашу страну, убедить их в том, что лучших или худших народов нет и быть не может. Главное - что собой представляет тот или иной человек, каков он сам по себе, а не какой он национальности. Эта мысль подтверждается народной мудростью, которая гласит: «Плохих народов не бывает, бывают плохие люди». А последние, как показывает практика, к сожалению, есть везде, среди любых этносов. Это определяется, прежде всего, тем, что ныне в силовом поле глобализационных конфликтов человек испытывает огромные не только физические, психологические, но и духовные перегрузки. В результате мы нередко имеем дело с вспышками насилия, агрессивности, с обвинением друг друга в порой надуманных и не имеющих права на существование домыслах и не проверенных фактах.

Положение дел на данном направлении настоятельно требует приступить к разработке системных мер как на научном, так и на общественном уровнях. Особое внимание при этом должно уделяться стабилизации экономических и социальных процессов в жестких условиях современного миропорядка; усилению доверия и сотрудничества в духовно-нравственной сфере жизни общества и в первую очередь в области культуры и образования; формированию умений культуры межэтнического общения; освещению в средствах массовой коммуникации вопросов развития национальных культур; исключить появление публикаций, возбуждающих чувства негативного отношения и вражды к соседним народам, чаще пропагандировать их культуру, традиции и обычаи.

Особого внимания заслуживает идея формирования биментальной и бикультурной личности, что откроет возможность решения очень трудной и важной задачи синтеза «национальных» устремлений с вектором интеграции цивилизационной целостности, которая возникла на базе русской культуры и русского языка. Русский язык должен вернуться на позиции языка межкультурного общения, стать закономерным явлением в жизни народов многонациональной России. Не отрывая людей от своих этнокультурных корней, он всегда способствовал усвоению ими русской духовной культуры, укреплению национального самосознания. Русский язык и культуру, по праву, можно считать важнейшими факторами, обеспечивающими межнациональное культурное единство при сохранении этнокультурной самобытности каждого из народов. Сегодня нашему обществу, как и человечеству, в целом, нужна когерентная культура, которая была бы построена на общих смыслах для всех этносов. И когда все общество примет ценности общего как главные ценности, то изменятся и смыслы, которые будут основаны на консолидации и межнациональном единстве.

Консолидация и единство межнациональных отношений предполагает поиск соответствующей базы (основы), идеи вокруг которой можно объединить и сплотить все общественные и политические силы общества. Сегодня общественному мнению предлагаются самые различные варианты национальной идеи: от «сбережения россиян» (А.И. Солженицын) до цивилизационного решения экологических проблем. Вне всякого сомнения, эти и многие другие точки зрения имеют право на жизнь. Однако все они лишены главного - философского стержня, той основы, которая на протяжении многих веков скрепляла нашу нацию, помогала ей не только выстоять в самых трагических баталиях своего времени, но и победить. Для нашего народа таким стержнем, такой основой всегда был, есть и останется патриотизм. Как заявил Президент Российской Федерации В.В. Путин «У нас нет никакой и не может быть никакой другой объединяющей идеи кроме патриотизма. Это и есть национальная идея» [7].

Эта мысль представляется нам наиболее значимой и актуальной и не только потому, что она прозвучала из уст главы государства, но и потому что она в большей степени отражает сущностную сторону российского патриотизма, концентрирует в себе его ценностные особенности, которые во все времена определяли специфику национального характера нашего народа, его ментальность и духовную культуру. Российский патриотизм во многом объясняется эмоциональным миром человека. Он пробуждает чувства бескорыстной любви к Родине, к своему Отечеству, национальную гордость, дух народа, способствует воспитанию, закреплению и преумножению многовековых традиций[2, с.22-27]. По мнению В.Г. Белинского «любить свою родину значит пламенно желать, видеть в ней осуществление идеала человеческого и по мере сил своих споспешествовать этому» [1, с.488-489].

Однако, любая идея какой бы она не была научно обоснованной и привлекательной так и останется идеей вопрошания самой о себе если в ее центре, говоря словами Протагора, не будет находиться человек как мера всех вещей. Сегодня важно чтобы преобладающее большинство населения страны видело пусть на горизонте или даже за горизонтом (в отдаленной перспективе) заботу и внимание со стороны государства, всех его властных структур о каждом человеке, видело и гордилось успехами своей страны во всех сферах жизни общества. Важно, чтобы, наконец, справедливость стала непреложным законом жизни всех и каждого. Только в таком случае можно реанимировать предложенную идею и придать ей необратимый вектор направленности.

Открытым остается и вопрос: вокруг какого центра следует консолидировать общество? Им, как нам пред- 
ставляется, может быть общенациональный лидер, наиболее популярная в народе политическая или общественная структура, а возможно и государственная организация. Определяющая роль в единении и сплочении этносов нашей страны принадлежит русскому народу. Русский - это не национальность, это интернациональность; по своей сути это носитель добра, дружбы и взаимопомощи. В абсолютном большинстве своем он обладает высочайшим трудолюбием, сильной волей, высокой ответственностью и решительностью. Русский народ - это образец мудрости и гуманизма, это великий народ, народ-созидатель. В веках запечатлена его помощь и поддержка многочисленных этносов России в развитии культуры, образования, экономической, социальной и духовной сфер жизни народов нашей страны.

В заключение следует подчеркнуть: проблемное поле сохранения целостности российского общества содержит больше вопросов чем ответов. Ясно одно: нужны срочные меры, в том числе и на уровне философского знания, чтобы активизировать работу по вхождению наших народов в единое пространство социокультурного общения, сближения их культур, языков, обычаев и традиций, выравниванию уровней экономического и социального развития. Межнациональное единство и консолидация выступают в качестве важнейших требований времени, являются главными условиями развития страны, становления гражданского общества. Сегодня следует еще раз вернуться к своим истокам, восстановить историческую преемственность, вспомнить времена великого князя Владимира, когда мы были единым русским народом, и не просто были, но и гордились тем, что принадлежим к этому народу, который в самых сложных исторических условиях смог собраться под единым целым и неделимым, название которому Русь-Россия.

\section{ЛИТЕРАТУРА}

1. Белинский В.Г. Полн. собр. соч.: в 13 т. Т.4.Статьи и рецензии 1840-1841. М.: Изд-во АН СССР, 1954. 934с.

2. См.: Бокачев И.А., Баранов С.Т., Незнамова И.И. Патриотизм и национальная идея России// Научное мнение. 2019. №4. 124с.

3. См.: Гасанов Н.Н. Межнациональное согласие - главное условие развития России//Социально-гуманитарные знания. 2012.№5.368с.

4. Колин К.К. Духовная культура как фактор обеспечения национального единства// Социально-гуманитарные знания. 2011.№4.368с.

5. Малахов В.С. Идентичность // Новая философская энциклопедия. - 2-е изд., испр. и допол. - М.: Мысль, $2010.560 с$.

6. Политология. Энциклопедический словарь - под ред. С.А. Ильина. - М., 1993. 329с.

7. Путин В.В. Выступление на заседании «Клуба лидеров» 03.02.2016- Центр Сулакшина. VRL: http://rusrand.ru/response/putin-patriotizm_eto-nationalnayaideya-rossi (дата обращения 12.01.2021)

( Б Бокачев Иван Афанасьевич, Незнамова Ирина Ивановна (irinanez@yandex.ru). Журнал «Современная наука: актуальные проблемы теории и практики» 